\title{
PENDAMPINGAN PENYUSUNAN PERANGKAT PEMBELAJARAN UNTUK MENGIMPLEMENTASIKAN KURIKULUM 2013 BAGI GURU SD BAITUL FATAH SURABAYA
}

\author{
Oleh \\ Woro Setyarsih, Nugrahani Primary Putri, Abdul Kholiq, dan Dzulkiflih *)
}

\begin{abstract}
Abstrak
Pelaksanaan Kurikulum 2013 memunculkan beberapa masalah khususnya di Sekolah Dasar diantaranya adalah proses melakukan penilaian hasil belajar. Menyikapi hal ini Tim PKM melakukan pendampingan dalam penyusunan perangkat pembelajaran untuk mengimplementasikan Kurikulum 2013. Kegiatan diawali dengan pemaparan materi untuk mendapatkan kesamaan konsepsi Kurikulum 2013 dan pemaparan prosedur penyusunan perangkatnya dilanjutkan dengan workshop penyusunan perangkat, lalu penerapan perangkat dalam pembelajaran di kelas diikuti proses brainstorming untuk melakukan refleksi dari pembelajaran yang telah dilakukan, dan terakhir merevisi perangkat pembelajaran sesuai dengan hasil refleksi. Kemampuan guru-guru SD Islam Baitul Fatah Surabaya dalam penyusunan perangkat pembelajaran sesuai Kurikulum 2013 mengalami peningkatan rata-rata (gain skor) antara 0,31-0,33. Peningkatan tersebut terjadi pada 8-12 aspek dari 14 aspek pengamatan. Kendala para guru selama menerapkan perangkat pembelajaran di kelas diantaranya penguasaan materi pelajaran kurang, melaksanakan pembelajaran kurang runtut, dan kurang dapat mengaitkan pembelajaran dengan kehidupan sehari-hari (tidak kontekstual). Kreativitas para peserta nampak dalam pembuatan media pembelajaran dan mengupayakan alat peraga untuk proses pembelajarannya.
\end{abstract}

Kata kunci: Kurikulum 2013, workshop, penilaian

\begin{abstract}
The implementation of the curriculum 2013 gave some problems, especially in primary schools including the assessment of learning outcomes. Based on this case, PKM team give a guidance in the preparation of teaching materials for implementing Curriculum 2013. The activity was initiated with the discussion of the topic based on Curriculum 2013. Then, proceed with the preparation of the teaching materials, and the application of the teaching materials in the classroom that is forwarded to the brainstorming process to reflect on the learning that has been done, and last revised the teaching materials in accordance with the result of reflections. The ability of elementary school teachers of Baitul Fatah Islam Surabaya in the preparation of the teaching materials suitable with curriculum 2013 increased an average (gain scores) between 0.31 to 0.33 . This increase occurred at 8-12 aspects of 14 aspects of observation. Obstacle's teachers for implementing the learning in the classroom are mastery of the subject less, implementing the learning less coherent, and unable to associate learning with everyday life (not contextual). Creativities teachers presented in the making of instructional media and demonstration tools for the learning process.
\end{abstract}

Keywords: Curriculum 2013, workshop, assessment

\section{PENDAHULUAN}

\section{Kurikulum 2013 telah dicanang- kan 2 tahun yang lalu dan telah}

diterapkan pada kelas I, IV, VII, dan X. Sesuai dengan Pedoman Pelatihan Implementasi Kurikulum 2013

*) Dosen di Juusan Fisika, Fakultas MIPA, Unesa 
(Kemendikbud, 2013:13), guru SD telah mendapatkan 2 kali pelatihan, yaitu pada pelaksanaan pengajaran di semester I dan pelaksanaan pengajaran di semester II. Selama pelaksanaan proses pembelajaran di kelas, guru akan dibimbing oleh Kepala Sekolah dan Pengawas. Disamping itu, guru juga akan mendapatkan program pendampingan pelaksanaan kurikulum 2013 dari Guru Inti. Namun demikian, tidak semua guru SD di wilayah Surabaya termasuk SD Baitul Fatah Surabaya, mendapatkan kesempatan pelatihan dan pendampingan secara langsung seperti di atas, sehingga kegiatan pendampingan serupa amat sangat diperlukan bagi guru-guru yang belum memperoleh kesempatan tersebut.

SD Baitul Fatah mempunyai 12 orang guru dan pada tahun 2013, 5 orang guru telah mengikuti pelatihan Kurikulum 2013. Pada tahun ini, 2 dari 5 orang guru yang pernah mengikuti pelatihan, kembali mengikuti pelatihan yang diselenggarakan oleh dinas setempat. Berdasarkan wawancara dan diskusi saat kunjungan, diperoleh informasi bahwa para guru masih mengalami kesulitan dalam menerapkan penilaian hasil belajar siswa. Menurut Kurikulum 2013, penilaian hasil belajar siswa yang sebenarnya adalah penilaian otentik, yaitu penilaian yang berbasis kegiatan aktual yang dilakukan siswa selama proses pembelajaran berlangsung. Dengan demikian, penilaian yang dilakukan adalah penilaian aktivitas siswa baik aktivitas kognitif (produk), aktivitas kinerja (psikomotor), maupun aktivitas afektif (sikap) yang diukur dan dinilai saat proses pembelajaran ber-langsung. Secara teknis penilaian tersebut bergantung jenis aktivitas yang dilakukan siswa. Para guru perlu merumuskan dan merancang dengan baik aktivitas siswa yang bagaimana yang akan dinilai sebagai hasil belajarnya. Hal tersebut juga dipengaruhi oleh pendekatan/ metode pembelajaran yang digunakan guru dalam pembelajarannya.

Kurikulum 2013 menegaskan bahwa pendekatan yang digunakan dalam pembelajaran adalah scientific approach. Dengan demikian, aktivitas siswa harus mengacu pada pendekatan scientific tersebut. Pemahaman guru akan pendekatan tersebut sangat menentukan aktivitas siswa dalam kegiatan pembelajarannya. Penjabaran pendekatan scientific tersebut ke dalam bentuk aktivitas siswa menjadi kata kunci yang tidak bisa ditawar lagi bagi para guru. Bila penjabaran yang dilakukannya tepat dan sesuai, maka guru tidak akan mengalami kesulitan dalam melakukan penilaian hasil belajar.

Berdasarkan uraian tersebut dan pengalaman melaksanakan pendampingan di SD selama ini, maka perlu mengurai terlebih dahulu pokok permasalahannya sebelum menyelesaikan masalah yang sekarang dihadapi. Tim PKM telah bersepakat untuk melakukan penyamaan konsepsi Kurikulum 2013 terkait penjabaran pendekatan scientific dalam pembelajaran sebelum melakukan pendampingan tentang penilaian hasil belajar siswa. Tentu saja semuanya bermuara pada rencana pelaksanaan 
pembelajaran yang dirancang guru sebelum dilakukan pembelajaran. Untuk itu kegiatan PKM kali ini diarahkan untuk melakukan pendampingan dalam menyusun perangkat pembelajaran sesuai dengan tuntutan Kurikulum 2013 dengan fokus pada penjabaran pendekatan scientific dalam proses pembelajaran.

\section{METODE PELAKSANAAN}

PKM pendampingan penyusunan perangkat pembelajaran yang dilaksanakan pada tahun 2014 ini merupakan kegiatan PKM lanjutan dari kegiatan pendampingan yang telah dilakukan tim dosen Jurusan Fisika pada tahun 2013 di SDN Banyu Urip VI/367 Surabaya. Untuk dapat menjawab permasalahan dalam kegiatan ini dilakukan tahapan/alur kegiatan seperti dalam Gambar 1.

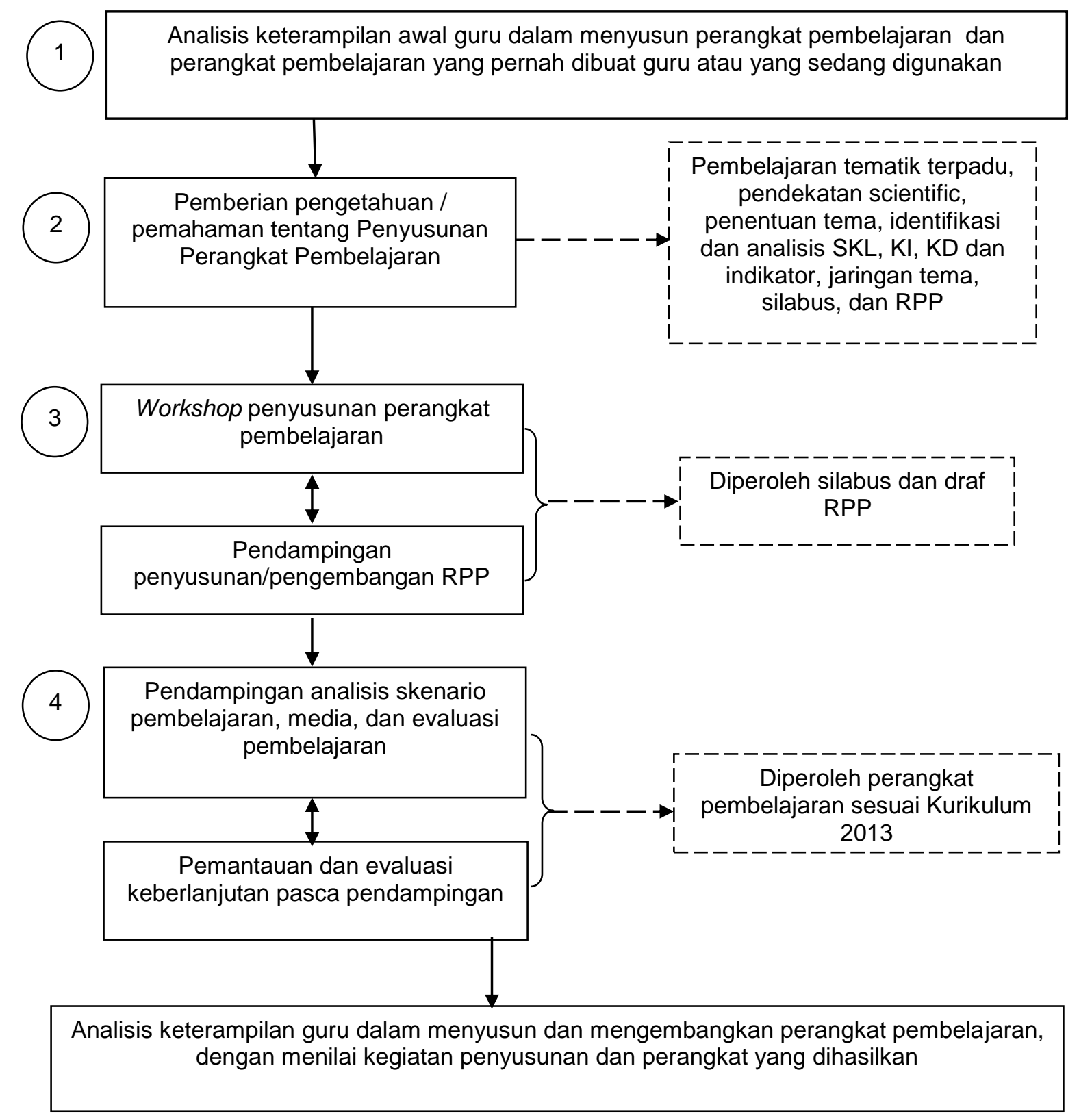

Gambar 1. Alur kegiatan pelaksanaan PKM 


\section{HASIL DAN PEMBAHASAN}

Kegiatan workshop menghasilkan perangkat pembelajaran yang belum lengkap, masih berupa draft RPP yang belum sempurna. Perlu tindak lanjut untuk menyempurnakan RPP dan melengkapi dokumen terkait seperti media yang digunakan, instrumen penilaian, LKS dan kuncinya. Berdasarkan pendampingan yang dilakukan, setiap kelas sudah berupaya membuat draft RPP meskipun rancangannya masih kasar dan belum terlihat adanya proses scientific dalam pembelajarannya. Ada dua guru yang cukup intens dalam bertanya dan berkonsultasi saat penyusunan, yaitu guru kelas II dan guru kelas V. Kepada beliau akhirnya diminta kesediaannya menjadi guru model saat proses penerapan RPP di kelas. Kelas V mengambil Tema Ke-3 yaitu Bermasyarakat, Sub Tema 1. BentukBentuk Kerukunan, Pembelajaran 2. Konsultasi yang dilakukan sampai pada media yang digunakan yaitu memakai alat peraga rangkaian listrik. Pihak pendamping bersedia memfasilitasi alat peraga tersebut saat akan digunakan. Sementara kelas II mengambil Tema 3. Kegiatanku Sehari-Hari, Sub Tema 2. Kegiatanku Sehari-Hari di Sekolah, pada Pembelajaran Ketiga. Guru kelas II sebagai Guru Model 1 (GM 1) dan Guru kelas V sebagai Guru Model 2 (GM 2).

Hasil yang dicapai dari kegiatan pendampingan yang telah dilakukan tercantum pada Tabel 1.

Tabel 1. Rekapitulasi hasil yang dicapai dari kegiatan pendampingan

\begin{tabular}{cll}
\hline No. & Aktivitas Kegiatan & \multicolumn{1}{c}{ Hasil Kegiatan } \\
\hline 1. & Pemaparan materi & Kesepakatan menerapkan strategi pembelajaran \\
& (makalah) & sesuai dengan pendekatan scientific dan metode \\
& & ilmiah seperti dalam Kurikulum 2013 pada perangkat \\
& & pembelajaran dan proses pembelajaran.
\end{tabular}

2. Workshop penyusunan perangkat pembelajaran
1. Draft Perangkat Pembelajaran, sebagai contoh draft: perangkat pembelajaran kelas II dan $\mathrm{V}$

2. Data kemampuan awal guru dalam menyusun perangkat (dari penilaian draft perangkat yang disusun)

3. Pembelajaran oleh guru

4. Refleksi di akhir model dan pengamatan observer pembelajaran

1. Data keterampilan guru menyampaikan pembelajaran di kelas

2. Data keterlaksanaan pembelajaran

3. Video proses pembelajaran guru model (kelas II dan Kelas V)

1. Data klarifikasi antara harapan, keinginan, rencana, dan fakta pembelajaran yang dilakukan guru

2. Data, saran, dan masukan pengamat untuk perbaikan perangkat pembelajaran

5. Pemantauan pasca
1. Perangkat pembelajaran yang telah direvisi (sesuai dengan Kurikulum 2013) 


\begin{tabular}{ccc}
\hline No. & Aktivitas Kegiatan & Hasil Kegiatan \\
\hline pendampingan & 2. $\begin{array}{l}\text { Data kemampuan guru dalam menyusun perangkat } \\
\text { pembelajaran setelah kegiatan pendampingan (dari } \\
\text { penilaian perangkat) }\end{array}$ \\
\hline
\end{tabular}

Analisis pertama dilakukan pada perangkat pembelajaran yang telah disusun para guru model. Penilaian awal dilakukan sebelum pelaksanaan pembelajaran. Penilaian akhir dilakukan setelah kegiatan pembelajaran dan refleksi bersama seluruh pengamat, dan telah dilakukan revisi. Hasil penilaian perangkat pembelajaran guru model terlihat pada Gambar 2.

Berdasarkan gambar tersebut, kedua perangkat dari Guru Model mengalami peningkatan skor pada beberapa aspek penilaian, sementara aspek yang lain tetap sama dengan skor penilaian awal. Aspek penilaian yang mengalami peningkatan pada kedua perangkat Guru Model tidak sama. Kemampuan Guru Model 1 (GM 1) mengalami peningkatan pada 8 aspek yaitu aspek ke-2, 3, 5, 7, 8, 11, 12, dan 13, meliputi aspek kesesuaian rumusan indikator pencapaian dan tujuan pembelajaran, kejelasan dan urutan materi ajar, kesesuaian strategi pembelajaran, kejelasan skenario pembelajaran, penilaian, kesesuaian teknik penilaian, dan kelengkapan perangkat penilaian. Sedangkan Guru Model 2 (GM 2) mengalami peningkatan pada semua aspek kecuali aspek ke-1 dan ke-7 yang tetap/tidak mengalami peningkatan, yaitu: kesesuaian antar kompetensi dasar dan kesesuaian strategi pembelajaran. Hasil penilaian perangkat pembelajaran berupa perubahan/ kenaikan dari perangkat awal dan akhir (revisi) kenaikan ataupun tidak ada perubahan/tetap, dapat diklarifikasi dari proses pelaksanaan pembelajaran yang dilakukan para guru model seperti pada Tabel 2.

Tabel 2. Hasil Penilaian Pelaksanaan Pembelajaran Para Guru Model

\begin{tabular}{crrrrr}
\hline \multirow{2}{*}{ No. } & \multicolumn{2}{c}{ Aspek yang diamati } & \multicolumn{2}{c}{ GM 1 } & \multicolumn{2}{c}{ GM 2 } \\
\cline { 3 - 6 } & & Skor & Kriteria & Skor & Kriteria \\
\hline I & PRA PEMBELAJARAN & 4,50 & Baik & 3,87 & Kurang \\
\hline II & KEGIATAN INTI PEMBELAJARAN & & & & \\
\hline A. & Penguasaan materi pelajaran & 3,95 & Baik & 3,87 & Kurang \\
\hline B. & Pendekatan/strategi yang digunakan & 4,03 & Baik & 3,58 & Kurang \\
\hline C. & $\begin{array}{l}\text { Pemanfaatan sumber belajar/media } \\
\text { pembelajaran }\end{array}$ & 4,27 & Baik & 3,92 & Baik \\
\hline D. & $\begin{array}{l}\text { Pembelajaran yang memicu dan memelihara } \\
\text { keterlibatan siswa }\end{array}$ & 4,33 & Baik & 3,92 & Baik \\
\hline E. & Penilaian proses dan hasil belajar & 4,40 & Baik & 3,25 & Kurang \\
\hline F. & Penggunaan bahasa & 4,30 & Baik & 3,75 & Kurang \\
\hline II & PENUTUP & 4,10 & Baik & 4,00 & Baik \\
\hline & & & & &
\end{tabular}




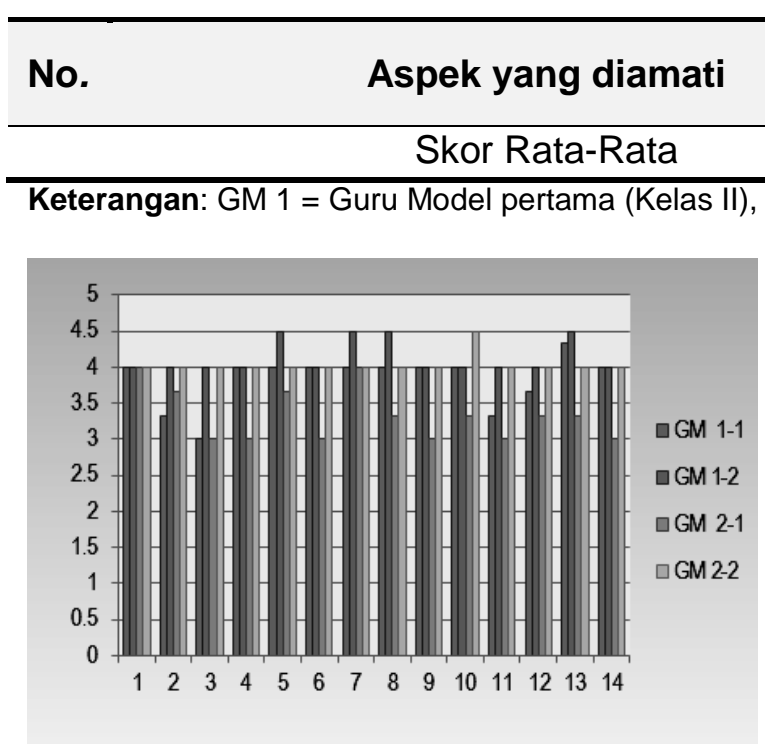

Gambar 2. Diagram batang skor penilaian perangkat pembelajaran para Guru Model

\section{Keterangan:}

GM 1-1 : Guru Model 1 - penilaian sebelum pembelajaran (awal)

GM 1-2 : Guru Model 1 - penilaian setelah pembelajaran (akhir)/revisi

GM 2-1 : Guru Model 2 - penilaian sebelum pembelajaran (awal)

GM 2-2 : Guru Model 2 - penilaian setelah pembelajaran (akhir)/revisi

1 : Kesesuaian antar kompetesi dasar dari $\mathrm{KI} 1, \mathrm{KI} 2, \mathrm{KI} 3$,dan $\mathrm{K} 14$

2 : Kesesuaian rumusan indikator pencapaian dengan kompetesi dasar (dari Kl1, $\mathrm{KI}$, $\mathrm{KI}$, dan $\mathrm{KI} 4$ yang akan dicapai)

3 : Kesesuaian perumusan tujuan pembelajaran dengan indikator pencapaian kompetisi

4 : Kesesuaian materi pembelajaran dengan indikator

\begin{tabular}{cccc}
\multicolumn{2}{c}{ GM 1 } & \multicolumn{2}{c}{ GM 2 } \\
\hline Skor & Kriteria & Skor & Kriteria \\
\hline 4,18 & Baik & 3,76 & Kurang \\
\hline
\end{tabular}

4,18 Baik

dan kompetisi dasar yang akan dicapai

5 : Kejelasan dan urutan materi ajar

6 : Kesesuaian strategi pembelajaran (metode dan pendekatan) dengan tujuan pembelajaran dan materi ajar

$7 \quad$ : Kesesuaian strategi pembelajaran dengan karakteristik peserta didik

8 : Kejelasan skenario pembelajaran (langkahlangkah kegiatan pembelajaran) dengan tujuan yang akan dicapai

9 : Skenario pembelajaran (langkah-langkah kegiatan pembelajaran) menggambarkan active learning dan scientific learning

10 : Ketepatan kegiatan penutup dalam pembelajaran

11 : Penilaian mencakup aspekaspek kompetesi dasar $\mathrm{KI} 1, \mathrm{KI} 2, \mathrm{KI}$, dan $\mathrm{KI} 4$ yang harus dicapai

12 : Kesesuaian teknik penilaian dengan indikator/kompentesi yang akan dicapai

13 : Kelengkapan perangkat penilaian (soal, kunci, dan rubrik penilaian)

14 : Keterpaduan dan kesinkronan antar komponen dalam RPP

GM 1 telah melaksanakan pembelajaran mulai kegiatan awal (pra pembelajaran) hingga kegiatan akhir 
(penutup) (meliputi 24 aspek yang diamati) dengan baik. Data pengamatan ini mendukung data penilaian perangkat yang menunjukkan adanya peningkatan pada 8 aspek dan 6 aspek yang skornya tetap. GM 1 telah memahami bagaimana menerapkan pendekatan scientific dan penilaiannya dalam perangkat pembelajaran sehingga skor penilaian pelaksanaan dalam kategori baik dan peningkatan skor penilaian perangkat hanya pada 8 dari 14 aspek penilaian (57\%). Sementara GM 2 belum cukup baik dalam menerapkan pendekatan scientific dan penilaiannya dalam perangkat pembelajaran, sehingga skor penilaian pelaksanaan dalam kategori kurang kecuali aspek sumber belajar/media pembelajaran dan pembelajaran yang memicu keterlibatan siswa memiliki skor dalam kategori baik. Hal ini amat sinkron dengan hasil penilaian perangkat pembelajaran yang menunjukkan perubahan/kenaikan pada hampir semua aspek, yaitu 12 aspek dari 14 aspek yang dinilai (85\%). Perubahan (gain) skor hasil penilaian perangkat pembelajaran tampak pada Tabel 1. Guru model 1 (GM 1) memiliki gain skor rata-rata $0,31(7,75 \%)$ dan guru model 2 (GM 2) memiliki gain skor rata-rata $0,33(8,25 \%)$.

\section{SIMPULAN DAN SARAN}

\footnotetext{
Kegiatan PKM dalam penyusunan perangkat pembelajaran telah terlaksana dengan baik dan mendapat respon positif dari guru sebagai peserta. Adapun simpulan dari kegiatan PKM ini adalah:
}

1. Kemampuan guru-guru SD Islam Baitul Fatah Surabaya dalam penyusunan perangkat pembelajaran sesuai Kurikulum 2013 mengalami peningkatan rata-rata (gain skor) antara 0,31-0,33. Peningkatan tersebut terjadi pada 8-12 aspek dari 14 aspek pengamatan.

2. Kendala para guru selama menerapkan perangkat pembelajaran di kelas diantaranya penguasaan materi pelajaran kurang, melaksanakan pembelajaran kurang runtut (masih terpotong-potong), dan kurang dapat mengaitkan pembelajaran dengan kehidupan sehari-hari (tidak kontekstual).

3. Kreativitas para guru sudah tampak dalam pembuatan media pembelajaran dan mengupayakan alat peraga untuk proses pembelajarannya.

\section{DAFTAR PUSTAKA}

Rohmatiah, 2014. Pengembangan Keprofesian Berkelanjutan: Tantangan Menuju Profesionalisme, (http://www.lpmpsulsel.net/v2/index .php?option=com, diakses pada tanggal 26 April 2014)

Yani, Ahmad, 2008. Penyusunan Model PTK (Untuk Memenuhi 12 Point Kenaikan Pangkat ke IVB). Disampaikan pada Lokakarya Implementasi Model PTK dan Model Lesson Study, 2-3 Desember 2008, FPIPS, UPI Bandung.

Anonim. Tanpa tahun. Konsep Pembelajaran Tematik Terpadu. Badan Pengembangan SDM Pendidikan dan Kebudayaan dan Penjaminan Mutu Pendidikan. 
Kementerian Pendidikan dan Tahun 2014, SD Kelas I, Badan Kebudayaan. Pengembangan SDM Pendidikan

Anonim. Tanpa Tahun. Implementasi dan Kebudayaan dan Penjaminan Mutu Pendidikan. Kementerian Pembelajaran Tematik Terpadu. Badan Pengembangan SDM Pendidikan dan Kebudayaan.

Pendidikan dan Kebudayaan dan Penjaminan Mutu Pendidikan. Kementerian Pendidikan dan Kebudayaan.

Anonim. 2014. Materi Pelatihan Guru, Implementasi Kurikulum 2013 
ADDD, Vol. 1, No. 1, Juni 2015, hal. 25 - 32

ISSN: 2460-5514 